TEME, г. XLI, бр. 2, април - јун 2017, стр. 371-390

Прегледни рад

Примљено: 11. 5. 2016.

DOI: $10.22190 /$ TEME1702371D

Ревидирана верзија: 26. 7. 2016.

UDK $81^{\prime} 42: 070.449 .8=163.41$

Одобрено за штампу: 15. 6. 2017.

741.5:314.7

\title{
МУЛТИМОДАЛНОСТ И МИГРАНТСКА КРИЗА У ДНЕВНОЈ ШТАМПИ НА СРПСКОМ ЈЕЗИКУ
}

\section{Татјана Ђуровић}

Универзитет у Београду, Економски факултет, Београд, Србија

tdjurovic@sbb.rs

\begin{abstract}
Апстракт
Кроз синергију области когнитивне лингвистике (Lakoff \& Johnson, 1980; Johnson, 1987; Charteris-Black, 2004; Benczes, Barcelona, \& Ruiz de Mendoza Ibáñez, 2011) и мултимодалности (El Refaie, 2003; Forceville, 2009; Forceville \& Urios-Aparisi, 2009; Bounegru \& Forceville, 2011), у раду се бавимо улогом сликовних и мултимодалних метафора у структурисању европске мигрантске кризе у дневној штампи на српском језику. Анализу заснивамо на узорку од дванаест карикатура објављених 2015. године у електронским издањима два дневна медија, конкретно у Политици и Вечерњим новостима. Циљ нашег истраживања је двојак: а) установити како визуелне метафоре, употребљене самостално или у спрези са вербалним метафорама, оваплоћују два когнитивна модела - САДРЖАВАњЕ и КРЕТАЮЕ и на њима засноване метафоре ЗИДА, КУЋЕ, ПУТОВАЊА, те тако доприносе концептуализацији учесника у мигрантској кризи; б) открити како се визуелним и/или вербалним реализацијама метафоре и других когнитивних инструмената преносе вредносна одређења и мање или више прикривени идеолошки ставови.
\end{abstract}

Кључне речи: српски језик, сликовне схеме, мономодалне и мултимодалне метафоре, мигрантска криза, карикатуре.

\section{MULTIMODALITY AND THE MIGRANT CRISIS IN SERBIAN NEWSPAPER CARTOONS}

\begin{abstract}
Complementing a wide theoretical framework of cognitive linguistics (Lakoff \& Johnson, 1980; Johnson, 1987; Charteris-Black, 2004; Benczes, Barcelona, \& Ruiz de Mendoza Ibáñez, 2011) with multimodality (El Refaie, 2003; Forceville, 2009; Forceville \& Urios-Aparisi, 2009; Bounegru \& Forceville, 2011), the paper explores the role of pictorial and multimodal metaphors in structuring Europe's migrant crisis in Serbian daily newspapers. The data collection for our analysis consists of twelve cartoons pertaining to the topic of migrant crisis published in daily newspapers Politika and Večernje novosti in 2015. The aim of our investigation is twofold: a) to determine how visual metaphors, independently or in a symbiosis with verbal metaphors, render two cognitive schemas -
\end{abstract}


CONTAINMENT and MOVEMENT and the metaphors of WALL, HOUSE, JOURNEY, thus contributing to the conceptualisation of the major participants in the migrant crisis; and $b$ ) to reveal how visual and/or verbal modalities of metaphor and other cognitive instruments convey an axiological value and more or less covert ideological stances.

Key words: Serbian, image schemas, monomodal and multimodal metaphors, migrant crisis, cartoons.

\section{УВОД}

Један од најупечатљивијих догађаја који је обележио 2015. годину, а судећи по најновијим дешавањима, и даље ће бити врло актуелан, јесте мигрантска криза - масовна кретања људи из одређеног броја земаља Блиског истока и Северне Африке захваћених ратом и сукобима ка Европској унији (ЕУ) као крајњем одредишту. Важна тачка која се налази на тзв. балканској рути јесте и Србија, преко које мигранти настоје да стигну најпре до „обода” ЕУ, тј. Мађарске, а одатле и до богатијих држава Уније, превасходно Немачке и Шведске. Услед несмањених ратних дејстава у Сирији, али и због вишегодишњих нестабилности у Авганистану, Ираку и Сомалији, број избеглих људи у појединим земљама ЕУ непрестано се повећава. Уз то, дубоко подељена схватања унутар држава чланица у погледу решавања мигрантске кризе, испољених у „квотама”, по којима би чланице Уније примале мигранте, довело је до тога да су одређене државе ЕУ одлучиле да или онемогуће или успоре пролаз миграната до средишта Уније под плаштом различитих економских, политичких и других разлога. Поједине драстичне мере озбиљно угрожавају идеју о слободном кретању људи и Европи без граница као једном од „стубова" постојања ЕУ. Отуд многе државе које се или налазе на мигрантској рути, попут Србије, или су крајња дестинација миграната непосредно су заинтересоване за ову сложену друштвену појаву која добија огроман простор у медијском извештавању. Медији на српском језику у том погледу нису изузетак и такође се у великој мери баве далекосежним последицама масовних мигрантских кретања.

Предмет истраживања у овом раду јесте мултимодални приказ мигрантске кризе у дневној штампи у Србији. Полазећи од основног постулата когнитивнолингвистички утемељене теорије мултимодалности (Forceville, 2009; Forceville \& Urios-Aparisi, 2009; Bounegru \& Forceville, 2011) да се метафора као механизам мишљења (Lakoff \& Johnson, 1980) може реализовати не само језички - вербално већ и невербално, тј. сликовно, на узорку карикатура из два дневна листа, конкретно из Политике и Вечерњих новости, истражујемо како карикатуристи користе визуелне и вербалне реализације когнитивних модеЛа САДРЖАВАЊА и КРЕТАҢА и с њима повезане метафоре и метонимије како би метафорички структурисали сложену друштвену 
појаву каква је мигрантска криза и истакли учеснике у овој кризи, пре свега ЕУ. Тачније, наше истраживање има двоструки циљ: 1) открити и описати језичка и нејезичка средства помоћу којих се реализују сЛИКОВНе схеме САДРЖАВАҢА и КРЕТАҢА и метафоре ЗИДА, КУ$\mathrm{hE}$, ПУТОВАњА, као изворних домена на основу којих можемо да разумемо циљни домен - МИГРАНТСКУ кРИзУ и односе међу њеним главним учесницима; 2) открити како се визуелним и/или вербалним модалитетима метафоре и других когнитивних инструмената преносе вредносна одређења и мање или више прикривени идеолошки ставови како би се усмерила друштвена акција и створио одређен поглед на друштвену стварност.

\section{ТЕОРИЈСКИ ОКВИР}

Мигрантска кретања постала су последњих година значајна тема превасходно интердисциплинарних истраживања. Тако се у истраживању дискурса са наглашено вредносним и идеолошким димензијама, какав је дискурс о мигрантима, примарни теоријски оквир оваквих студија - критичка анализа дискурса (КАД) (Reisigl \& Wodak, 2001; Hart \& Cap, 2014) прожима са когнитивном лингвистиком (КЛ) (Lakoff \& Johnson, 1980; Charteris-Black, 2004) и једним од њених централних феномена проучавања - појмовном метафором. Појмовна метафора дефинише се као разумевање искуствено и појмовно даљег ентитета - циљног домена, на основу познатијег и конкретнијег ентитета - изворног домена. Одабир који се путем метафоре и њених језичких реализација (метафоричких израза) прави зарад истицања одређених аспеката појма, а прикривања неких других аспеката истог појма - омогућава да се открију мање или више прикривени вредносни обрасци у тексту и начину концептуализације. Улога појмовне метафоре и других когнитивних инструмената у поимању миграције превасходно се испитује у јавном дискурсу енглеског (Santa Ana, 2002; Charteris-Black, 2006; Hart, 2010; Musolff, 2011, 2015), али и других језика (El Refaie, 2001; Dervinytė, 2009; Ђуровић, 2015). У овим истраживањима издвајају се најчешћи видови метафоричког структурирања мигрантских кретања (преко метафора ПРИРОДНЕ КАТАСТРОФЕ, РАТА, ЖИВОТИњЕ, КОРОВА ИТД.) и УГЛаВНОМ негативно перцепирање кључних учесника у овој врсти дискурса миграната.

Како се савременим приступима метафори и другим когнитивним механизмима истражују не само начин њиховог остварења путем текста већ и кроз слику - тако расте број студија које когнитивнолингвистички теоријски оквир допуњују основним постулатима мултимодалности. У овом раду мултимодалност посматрамо из угла аутора Форсвила и његових сарадника (Forceville, 2008; Forceville \& 
Urios-Aparisi, 2009; Bounegru \& Forceville, 2011), који, полазећи од основног постулата о појмовној метафори као механизму мишљења, а не искључиво језика (Lakoff \& Johnson, 1980), сматрају да, поред вербалних, постоје и друге реализације метафоричког мишљења, оне невербалне природе, као што су слика, музика, звук, говор тела и слично. Најчешће истраживани облици невербалних метафора јесу мономодалне визуелне (сликовне) метафоре и мултимодалне метафоре. За разлику од мономодалних метафора, вербалних или сликовних, код којих се изворни и циљни домен остварују уз помоћ истог семиотичког система - језика или слике, мултимодалне метафоре дефинишу се као „метафоре чији се појединачни циљни и изворни домени описују искључиво или претежно различитим модалитетима" (Forceville, 2009, p. 24). Другим речима, мултимодалне метафоре су „метафоре код којих циљ[ни домен], извор[ни домен], и/или елементе пресликавања представљају или на њих указују барем два различита знаковна система (од којих један може бити језички) или начина перцепције" (Forceville, 2008, p. 24).

Мултимодални дискурс у поље истраживања уводи и метонимију, која, слично метафори, свом далеко проучаванијем појмовном пандану, такође представља моћно когнитивно средство помоћу којег стварамо, организујемо и разумемо стварност која нас окружује. За разлику од појмовне метафоре, где се делимично пресликавање једног домена на други одвија на основу сличности (Lakoff \& Johnson, 1980; Kövecses, 2010), код појмовне метонимије пресликавање се одвија унутар истог појмовног домена на основу блискости логичких веза (Radden \& Kövecses, 1999; Benczes, Barcelona, \& Ruiz de Mendoza Ibáñez, 2011). Пресликавање са једног домена на други у случају метафоре је симетрично, док је код метонимије оно асиметрично, односно истакнутији ентитет користи се да омогући ментални приступ другом, мање истакнутом ентитету унутар истог појмовног домена (Barcelona, 2011, p. 12). Са становишта мултимодалности, између метафоре и метонимије постоји још једна значајна разлика. Осим што се јавља у различитим модалитетима, појмовна метафора се често може реализовати кроз читав низ комбинованих модалитета (мултимодална метафора); појмовна метонимија се пак појављује мономодално, било као вербална, било као визуелна реализација (Negro Alousque, 2013, p. 366).

\section{КАРИКАТУРА И МУЛТИМОДАЛНОСТ}

Когнитивистички утемељена мултимодалност проучава се у различитим видовима дискурса и жанрова - реклама (Forceville, 2008; Koller, 2009), стрипова и филмова (Forceville \& Urios-Aparisi, 2009), насловница (Cortés de los Ríos, 2010; Ђуровић \& Силашки, 2013; Си- 
лашки \& Ђуровић, 2013). Мултимодалност у овом раду анализира се у оквиру жанра карикатуре, која, као један од начина представљања сложених друштвено-политичких појава, на сугестиван и пријемчив начин преноси поруку аутора широком читалаштву.

Главна сврха политичких карикатура јесте да на језгровит и надасве оригиналан, упечатљив и хумористичан начин прикажу различите аспекте друштвеног, културног и политичког живота (El Refaie, 2009, p. 176). Ауторка Негро Алоск (Negro Alousque, 2013, p. $370 ; 2014$, p. 66) издваја неколико обележја политичких карикатура, те пише да оне имају функцију дескрипције будући да су алузија на одређену друштвено-политичку ситуацију, догађај или личност. С обзиром на то да увек критички и сатирично приказују најновије догађаје, за правилну интерпретацију карикатура неопходно је знање о друштвеном и културном контексту у који су смештене. Карикатуре делују као спона између фикције и чињенице, а метафорички процес преношења значења из имагинарног у реално остварује се претежно на визуелан начин (El Refaie, 2009, p. 174).

Метафора је уобичајено средство у карикатурама и једно од главних „оружја” у „арсеналу” које карикатуристи стоји на располагању (El Refaie, 2003, p. 77). У том погледу, карикатуристи првенствено користе визуелно оваплоћење метафоре које спаја реалност и менталну слику коју су о реалности створили карикатуристи, трудећи се да „примене причу или мит који су познати читаоцима и тако повежу непознато са познатим" (Благојевић \& Ралевић, 2013, стр. 373). Будући да увек приказује одређени догађај или личност, слика је одређенија од речи и може да изрази нијансе значења које се понекад тешко могу пренети језиком (El Refaie, 2009, p. 177). Неретко карикатуре садрже и вербалне реализације и пример су мултимодалних, сликовно-вербалних метафора (El Refaie, 2003, 2009; Bounegru \& Forceville, 2011; Negro Alousque, 2013, 2014), које су предмет анализе и у овом раду. Сагледавање визуелне, сликовне метафоре на начин општеприхваћене парадигме у истраживању вербалних метафора у оквиру когнитивне лингвистике, тј. становишта да се и визуелне метафоре заснивају на појмовним доменима, методолошки је плодотворно јер омогућава да се значајно прошири начин на који се појмови изражавају путем слике. Истовремено, когнитивистички утемељена мултимодалност омогућава боље и делотворније поређење вербалних и визуелних реализација истог метафоричког појма (El Refaie, 2003, p. 81).

За разлику од великог броја радова, од којих смо неке горе поменули, а који обрађују тему миграната кроз спону КЛ и КАД, те вербалних реализација когнитивних структура, ова тема спорадично постаје предмет истраживања и у оквиру когнитивнолингвистички засноване мултимодалности (Martínez Lirola, 2008) и политичке карикатуре као жанра (El Refaie, 2003; Negro Alousque, 2013). У тим 
радовима се, кроз анализу примера из француске, аустријске и шпанске штампе, истраживачка пажња првенствено усмерава на визуелне модалитете метафоре и метонимије, као и улогу ових когнитивних инструмената у творењу значења.

\section{МЕТОДОЛОГИЈА ИСТРАЖИВАЬА}

Праћењем одређеног броја медија на српском језику у вези са темом мигрантске кризе увидели смо да се ова изузетно сложена друштвена појава приказује, осим кроз језик, и другим семиотичким средствима, сликом или цртежом. Предмет мултимодалне анализе под окриљем КЛ чини дванаест политичких карикатура објављених у нашој дневној штампи 2015. године. Од тога, шест карикатура су аутора Душана Петричића и објављене су у дневном листу Политика (21. јун 2015. год.; 9. август 2015. год.; 23. август 2015. год.; 20. септембар 2015. год.; 11. октобар 2015. год.; 1. новембар 2015. год.). Карикатуре из Политике преузете су са сајта http://www.politika.rs/scc/authors/satires/ 849. Други део чини такође шест карикатура, од тога четири карикатуре аутора Тоша Борковића (21. јун 2015. год.; 25. август 2015. год.; 14. септембар 2015. год.; 22. септембар 2015. год.) и две карикатуре аутора Горана Дивца (15. јул 2015. год.; 24. октобар 2015. год.), објављених у дневном листу Вечерње новости и преузетих са сајта http://www.novosti.rs/dodatni_sadrzaj/foto.110.html?galleryId=4\#image_.

Све карикатуре објављене су у 2015. години, када је мигрантска криза достигла драстичне размере како у транзитним земљама миграната, међу којима је и Србија, тако и у појединим државама ЕУ, као њиховом крајњем одредишту, што је условило да неке од њих, пре свега Мађарска и Хрватска, донесу одлуку о подизању зида да би заштитиле како националне границе тако и спољашње границе ЕУ и на тај начин отежале или онемогућиле пролаз наводно илегалних миграната до Немачке, срца Уније. Отуд се карикатуре понајвише односе на перципирање ЕУ из угла српских карикатуриста, а у вези са мигрантском кризом.

Више је разлога због чега смо се определили за карикатуре из Политике и Вечерњих новости. Прво, у два наведена листа мигрантска криза се редовно обрађује, не само језички већ и сликовно, у форми карикатуре, што нам је омогућило да заокружени корпус заснивамо на само два извора. Друго, и поред одређеног броја мономодалних, визуелних метафора, мигрантска криза се претежно приказује мултимодално, метафорама вербално-визуелног типа, посебно у карикатурама Душана Петричића у Политици. Треће, у свим карикатурама метафора је присутна у свом визуелном модалитету и односи се на мигрантску кризу као циљном домену. Најзад, све издвојене карикатуре имају наглашену евалуативну компоненту, коју подстиче однос слике или симбола и текста. У анализи карикатура применили 
смо методологију за идентификацију метафора у мултимодалном дискурсу по узору на Бунегри и Форсвила (Bounegru \& Forceville, 2011). Заснивајући своје истраживање на карикатурама објављеним у октобру 2008. године, а које се односе на глобалну финансијску кризу, Бунегри и Форсвил дефинишу три критеријума за идентификацију метафора: 1) једнакост се успоставља између два феномена која, у датом контексту, припадају различитим категоријама; 2) феномени се разумеју као два различита домена, циљни и изворни, и у датом контексту нису реверзибилни, тј. не могу заменити места; и 3) барем једно обележје/конотација изворног домена пресликава се на циљни домен; често се пресликава скуп појмовних кореспонденција, чији избор припада интерпретативном делу анализе метафора који пак подлеже не само жанровским особеностима политичке карикатуре већ и претпоставци да аутор карикатура критички приказује оне догађаје или личности из друштвене стварности који су најрелевантнији публици којој се обраћа (Bounegru \& Forceville, 2011, p. 213). Примењујући наведене поставке, у следећем поглављу анализирамо уочене мономодалне и мултимодалне метафоре, где је циљни домен увек МИГРАНТСКА КРИЗА или пак појава која је с кризом метонимијски повезана како бисмо установили доминантне изворне домене, вербалне и/или сликовне, те указали на њихову утемељеност у човековом физичком искуству и културном контексту. Уз то, настојимо да откријемо евалуативни садржај издвојених когнитивних структура, те њихову улогу у обликовању реалности. Анализа је квалитативна и у овом раду се не бавимо учесталошћу појединих начина приказа миграната у политичкој карикатури.

\section{МИГРАНТСКА КРИЗА У МУЛТИМОДАЛНИМ КАРИКАТУРАМА}

Мигрантска криза представља се у карикатурама дневне штампе у Србији визуелним или вербално-визуелним средствима која на појмовном плану оваплоћују преовлађујући когнитивни модел САДРЖАВАњА (са метафорама ЗИДА и КУЋЕ), те с њима повезани модел КРЕТАњА (с метафором ПУТОВАњА), који, заједно са појединим метонимијским реализацијама, доприносе концептуализацији учесника у мултимодалном дискурсу. Изворни домени често су, мање или више експлицитно, истовремено присутни на карикатурама. Због ограниченог простора, у раду ћемо детаљно описати осам карикатура, по четири из оба наведена медија - Политике и Вечерњих новости.

\section{Мигрантска криза у карикатурама листа „Политика”}

Прва карикатура (Слика 1) приказује рекламне паное најзначајнијих и најпопуларнијих европских туристичких атракција ограђених бодљикавом жицом, јасним симболом мигрантске кризе као 
циљног домена. У овој карикатури, примеру мултимодалне метафоpe, САДРЖАТЕљ Европска унија (метафора ДРЖАВА ЈЕ САДРЖАТЕЉ) је, путем двоструке метонимије ГРАД ЗА ДРЖАВУ ЗА ЕУ, представљена помоћу рекламних туристичких паноа градова, Прага, Рима, Фиренце, Париза, Франкфурта, Будимпеште, Беча. Рекламни панои реализују или визуелне метонимије (ЗНАМЕНИТОСТ ЗА ГРАД/ДРЖАВУ), као што су Колосеум или Ајфелова кула, и/или вербалне метонимије, тј. фигуративне изразе, попут „Град светлости” и „Краљица Дунава”, као метонимијских замена за Париз, односно Будимпешту. На овај начин активира се метафора КРЕТАњА тј. ПУТОВАҢА, са ЕУ, метонимијски представљеном преко одређеног броја градова, као крајњом, одредишном тачком. Отуд и вербални део карикатуре „Зов Европе” имплицира у појмовном смислу силу ПРИВЛАЧЕњА, која делује на други ентитет и узрокује његово кретање.

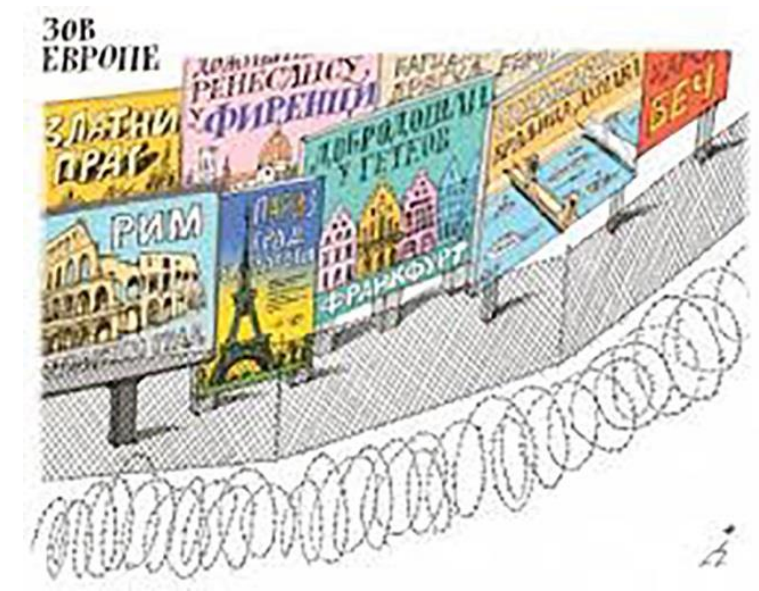

Слика 1. Политика, 9. август 2015. год. Наслов: Зов Европе

Међутим, да карикатура упућује на другачији карактер кретања од оног туристичког и у сврху забаве и упознавања других култура - открива се визуелно. Наиме, иако мигранти нису експлицитно представљени, визуелна метафора ЗИДА (структурни део схеме САДРЖАТЕЉА, који дели простор на унутрашњи и спољашњи део), тј. два реда бодљикаве жице који опасавају рекламне паное, поимају се и као физичка и као ментална препрека која ће заштитити САДРЖАНЕ ОБЈЕКТЕ од доласка „непожељних туриста”. Вербални део карикатуре „Зов Европе” доприноси вредносној оцени САДРЖАТЕЉА ЕУ, која се уз помоћ визуелне метафоре перципира као негостољубива и нерада да прихвати друге ентитете - мигранте. Тако визуелна метафора ЗИДА као део схеме САДРЖАВАњА служи на менталном плану 
као оправдано средство у заштити од миграната који се поимају као друштвена претња и сила, а заправо прикрива испољену нетолеранцију кроз сатирични вербални израз „Зов Европе”.

Наредна карикатура (Слика 2) такође је ефектан спој слике и текста и врло сугестивна у погледу концептуализовања ЕУ као двојако ограђеног САДРЖАТЕЉА: сама ЕУ визуелно је приказана као простор омеђен високим зидом који чувају чланице ЕУ, метонимијски представљене заставама својих држава. Но, уместо уобичајених боја и симбола који представљају заставу одређене земље, визуелно је представљена метафора ЗИдА, коју допуњује вербална реализација у виду наслова „,Уједињена Европа”, као фигуративни израз за ЕУ.

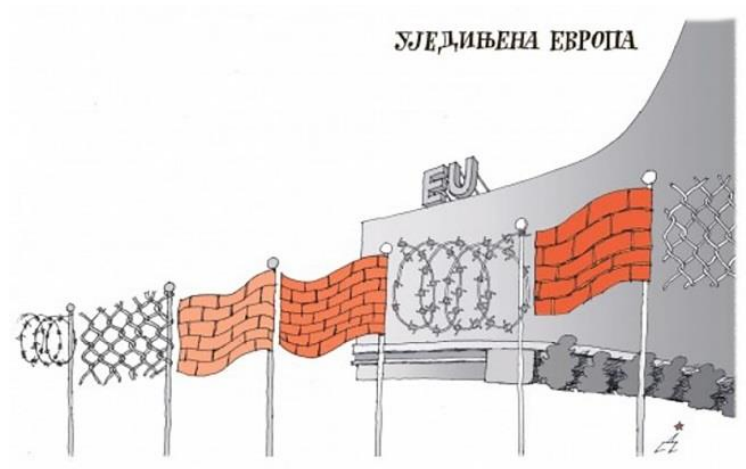

Слика 2. Политика, 1. новембар 2015. год. Наслов: Уједињена Европа

На „заставама” се „вијоре” различити облици бодљикавих жица и бетонских зидова, који су и на физичком и на појмовном плану „спољна граница” одбране САДРЖАТЕљА ЕУ, визуелно представљеног високим зидом и метонимијски латиничним словима „EU”. Поимање ЕУ као простора чије спољне границе од контекстуално призваних миграната, који се преко визуелних представа „застава” колективно посматрају као „илегални”, штите државе чланице разним барикадама и блокадама, не само на физичком већ превасходно на менталном плану, стапа се са насловом карикатуре „Уједињена Европа”. Ову карикатуру такође сматрамо примером мултимодалне метафоре, будући да би постојање визуелног модалитета без наслова и пропратног вербалног сигнала „ЕU” отежало интерпретацију карикатуре. У контексту актуелних дешавања у вези с мигрантском кризом, наслов „Уједињена Европа” носи снажну идеолошку поруку о Европи, која је уједињена у поимању „других“ као претеће силе од које се мора одбранити и не допустити јој да угрози унутрашње границе САДРЖАТЕЉА ЕУ. 
Трећа карикатура аутора Душана Петричића (Слика 3) још је један пример мултимодалне метафоре. Изворни домен САДРЖАВАњЕ и с њим повезана метафора ЗиДА визуелно се остварује преко различитих врста бетонских зидова и жичаних ограда, који сваки понаособ подвајају простор на два САДРЖАТЕљА (преко метафоре ДРЖАВА JЕ САДРЖАТЕљ), где се онај унутрашњи приказује као физички недоступан и заклоњен високим препрекама.

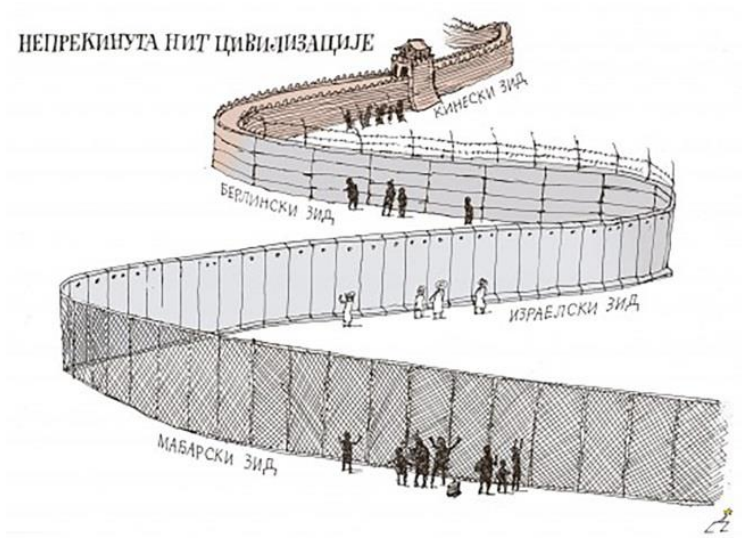

Слика 3. Политика, 21. јун 2015. год.

Наслов: Непрекинута нит цивилизаџије

За разлику од претходне две карикатуре, овде имамо визуелни приказ људи који се налазе „с друге стране” зида, тј. миграната на страни мађарског зида, те је тако циљни домен визуелно реализован. Издвојену карикатуру сматрамо мултимодалном јер и поред недвосмисленог сликовног приказа Кинеског зида, без вербалних разјашњења - Берлински зид, Израелски зид, Мађарски зид - не бисмо је интерпретирали као критику актуелне мигрантске кризе језички уобличеном насловом „Непрекинута нит цивилизације”. Кинески зид, Берлински зид, Израелски зид, Мађарски зид, визуелно и вербално - тумаче се као одраз многих дихотомија̂: „ми” насупрот „они”, „цивилизовани” насупрот „варвари”, „Запад” - „Исток” и осталих идеолошких, верских и друштвених поларизација. Додатну раван објашњења уводи вербална реализација „Непрекинута нит цивилизациje”, која језички снажно подупире поруку визуелне метафоре да су зидови као физичке, те менталне, представе подела обележје сваког периода историје људског друштва, а неназирање њиховог почетка ни краја, сугерисано и језички и нејезички, указује да ће овакво структурирање друштвених односа постојати и у будућности. Ипак, учинковитост предузетих друштвених активности како би се зауставила мигрантска кретања доводе у питање не само примери „зидова” 
са којима се у појмовном смислу пореди Мађарски зид већ и потенцијално позитивне конотације метафоре зидА као препреке коју људи желе да уклоне и сруше (Берлински зид).

Последња карикатура коју ћемо анализирати (Слика 4) садржи вишеслојне когнитивне елементе, али и снажно евалуативно одређење.

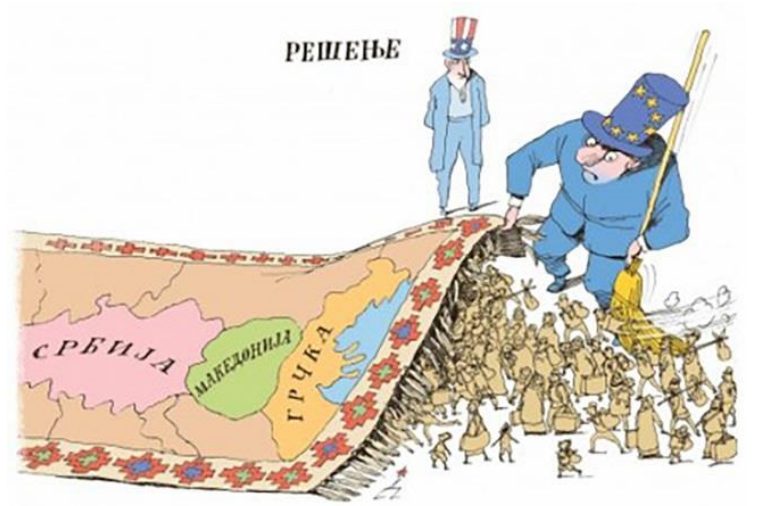

Слика 4. Политика, 23. август 2015. год. Наслов: Решење

Цртежом доминира фигура у оделу са цилиндром у бојама и симболима заставе ЕУ (златним звездицама), која тако представља ЕУ, што на појмовном плану твори метонимију ПОЈЕДИНАЦ ЗА ИНСТИТУцИЈУ преко метонимијског односа ДЕО ЗА ЦЕЛИНУ. Циљни домен МИГРАНТСКУ КРИзУ визуелно остварује слика миграната који су, преко метле којом их званичник ЕУ „чисти”, појмовно сведени на ОБЈЕКАТ КОЈИ СЕ КРЕЋЕ, отуд лишени аспекта људскости. Негативном поимању миграната доприноси и њихова величина у односу на две фигуре званичника, посебно оног који симболизује ЕУ, што представља визуелне реализације схеме ВЕРТИКАЛНОСТИ и метафора НЕМАњЕ МОЋИ ЈЕ ДОЛЕ, оДНосно МОЋ/КОНТРОЛА ЈЕ ГОРЕ. Но, ЕУ, Преко фигуре званичника ЕУ, губи контролу над кризом посежући за краткорочним, неделотворним решењима, што се визуелно оваплоћује кроз слику гурања миграната испод метафоричног тепиха ЕУ (чиме се активира схема САДРЖАВАњА) и пребацивање проблема на визуелно и вербално истакнуте државе на тзв. балканској рути: Грчку, Македонију и Србију (метафора МИГРАНТСКА КРИЗА ЈЕ БАЛКАНСКА РУТА), рути која је постала симбол „навале” миграната у срце Европе и узрок појаве нових зИдовА. Неделотворност реаговања ЕУ на мигрантску кризу одражава и наслов карикатуре „Решење”, који се повезује са сликом склањања миграната под „тепих” ЕУ, што конотира израз „гурати нешто под тепих”, те указује на тек привремено 
решавање важних друштвених проблема. Другим речима, вербалним одређењем само три САДРЖАТЕЉА (преко метафоре ДРЖАВА ЈЕ САДРЖАТЕљ) - Грчке, Македоније и Србије, испод којих је потребно „Почистити" мигранте, жели се нагласити неадекватан однос ЕУ у третирању последица кризе, али и нереална очекивања у погледу заустављања ОБЈЕКАТА КОЈИ СЕ КРЕЋУ - миграната. Карикатура приказује и фигуру која је такође преко недвосмислених симбола на цилиндру метоним за САД, а која је даља од ока посматрача у односу на фигуру ЕУ, чиме се указује на степен укључености САД у решавању мигрантске кризе. Миран израз лица фигуре која симболизује САД у односу на љутит израз фигуре ЕУ, као и руке које су код фигуре САД прекрштене на леђима, имплицирају нечињење и одсуство жеље за деловањем у погледу смиривања кризе и равноправног дељења терета, те је наслов карикатуре „Решење” сатиричан коментар на актуелну друштвену ситуацију. С обзиром на то да садржи и вербалне компоненте - Србија, Македонија и Грчка, које су важне за потпуну идентификацију изворног домена - КРЕТАњА, испреплетеног са САДРЖАВАњЕМ, ову метафору класификујемо као мултимодалну, вербално-визуелног типа.

\section{Мигрантска криза у карикатурама листа „Вечерње новости”}

Карикатура аутора Горана Дивца (Слика 5) приказује избегличку породицу пред вратима ЕУ која службеници ЕУ гурају рукама како би их држали затвореним и тако спречили улазак поменуте породице.

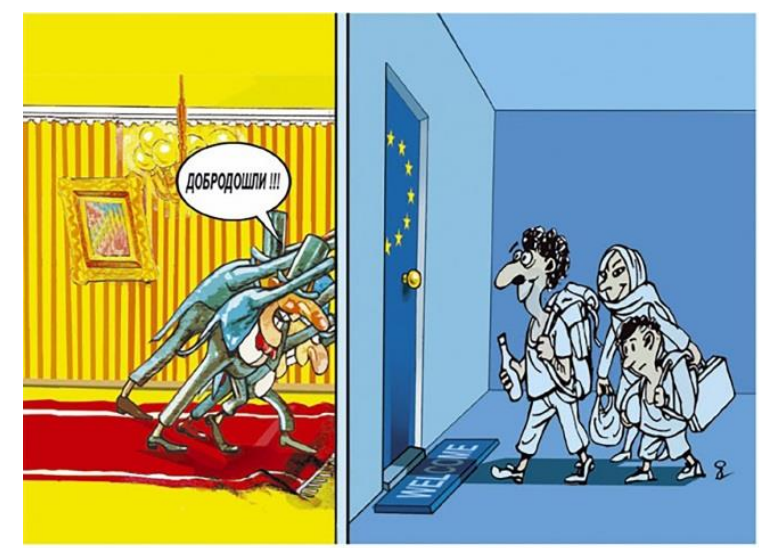

Слика 5. Вечерње новости, 24. октобар 2015. год. Наслов: Гости

Избегличка породица, визуелни метоним за све избеглице, налази се пред вратима куће ЕУ (метафора ЕУ JЕ КУЋА преко ЕУ JЕ СА- 
ДРЖАТЕљ, тј. ДРЖАВА ЈЕ САДРЖАТЕљ) УКрашеним зЛатним зВездицама и обојеним у плаво, јасним симболима и бојама заставе ЕУ. Иако су врата (структурни елемент куће, тј. ЕУ као КУЋЕ) део простора ЕУ, визуелним приказом успоставља се јасна подвојеност на простор изван ЕУ и онај унутар Уније (схема САДРжАВАњА). Визуелни део метафоре ослања се на две вербалне реализације истог значења „Welcome” и „Добро дошли”, које су у противуречности са сликом простора унутар ЕУ. Наиме, врата ЕУ, отуд САДРЖАТЕљ (КУЋУ) ЕУ, штите три службеника ЕУ, који са унутрашње стране спречавају улазак миграната перципираних као нежељени гости, заокружено и насловом карикатуре - „Гости”. Циничном тону карикатуре доприносе осмеси на лицима ЕУ званичника и вербални сигнал „Добро дошли”, док предузимају напоре да спрече улазак миграната са спољашњих граница ЕУ, визуелно представљених прагом (са натписом „Welcome”) у средиште, у кућу ЕУ, чиме се имплицира не само раскорак између званичне политике Уније према мигрантима и реалног стања већ и пораз залагања Немачке за тзв. политику „отворених врата” (овде визуелно назначеном црвеним тепихом). Иако се карикатура недвосмислено повезује са мигрантском кризом кроз визуелни модалитет, вербално сигнализирање - „Добро дошли” и „Welcome”, као и наслов карикатуре („Гости”), доприносе потпунијој интерпретацији карикатуре и одређењу визуелне метафоре. Визуелне реализације метафоре помогнуте вербалним, подвлаче перципирање ЕУ из угла једне од земаља (Србије) преко које мигранти прелазе у намери да стигну до свог циља, тј. истичу неискреност и недоследност европских званичника да нађу решење за мигрантску кризу.

Следећа карикатура (Слика 6), аутора Тоша Борковића, почива на сличним визуелним и вербалним реализацијама мигрантске кризе као и претходна карикатура. Мигрантска криза на појмовном плану приказује се кроз активирање сликовне схеме САДРЖАВАњА, те долазак испред зграде ЕУ (метафора ЕУ ЈЕ ЗГРАДА преко ЕУ тј. ДРЖАВА ЈЕ САДРЖАТЕљ), коју са обе стране улаза визуелно сигнализирају жуте звездице, један од симбола идентитета ЕУ са заставе ЕУ (метонимија ЧЛАН КАТЕГОРИЈЕ ЗА КАТЕГОРИЈУ). КарикаТуром доминира уЛаз у зграду ЕУ забарикадиран даскама на којима се суши натпис на енглеском језику „Welcome”, који исписује представник ЕУ. Циљни домен је визуелно присутан кроз слику миграната који чекају испред улаза зграде где је вербални сигнал поново у контрасту са визуелном реализацијом. Карикатура је критика „добродошлице” (што је и наслов карикатуре) ЕУ за мигранте, који се кроз визуелну реализацију затвореног улаза зграде ЕУ колективно поимају као илегални мигранти, те отуд и као друштвена претња чије се кретање и напредовање ка срцу ЕУ мора бар на неко време зауставити зидом од дрвених дасака. 


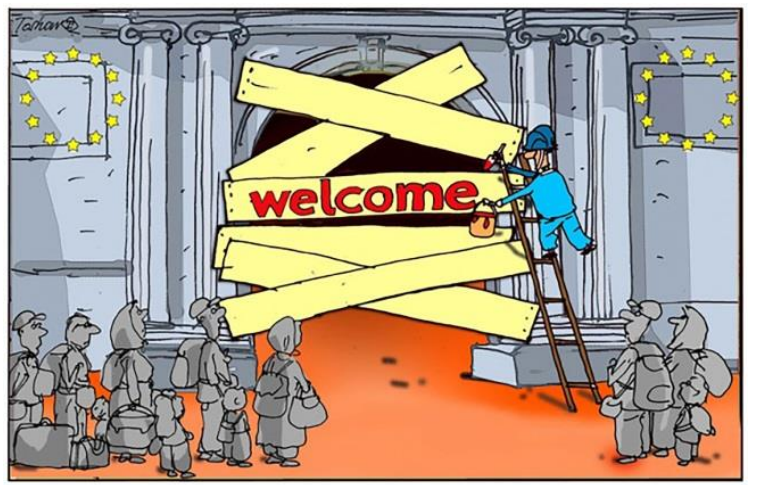

Слика 6. Вечерње новости, 22. септембар 2015. год. Наслов: Добродошлича

Слично претходној карикатури (Слика 5), и карикатура приказана на Слици 6 пример је вербално-визуелне метафоре где вербални модалитет има наглашену функцију евалуације - истицање дволичности политике ЕУ у решавању кризе, односно раскорак политике „отворених врата” Немачке и стварни третман миграната.

Претпоследњу карикатуру (Слика 7) сврстаћемо у мономодалну метафору, будући да једина вербална реализација. Наслов „Жица” упућује на исти изворни домен који је и визуелно оваплоћен - физичке препреке од жице (подигнуте на границама Мађарске и Хрватске са Србијом).

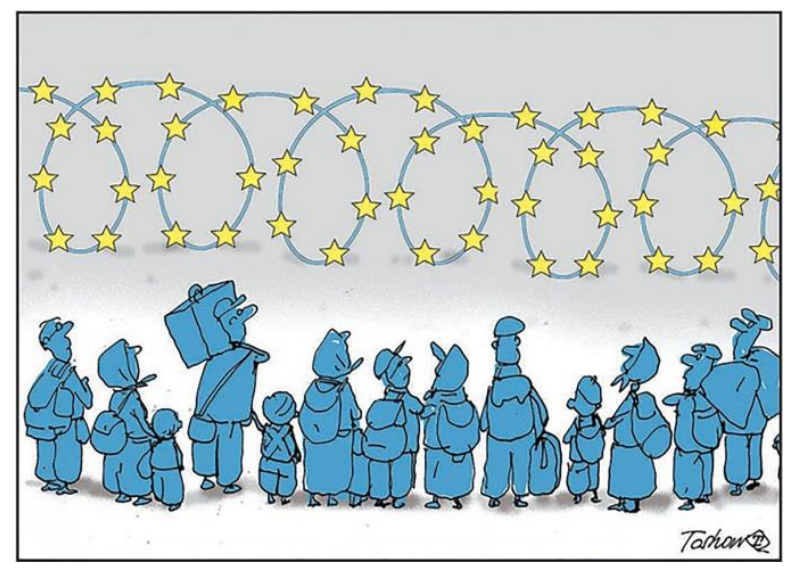

Слика 7. Вечерње новости, 14. септембар 2015. год. Наслов: Жииа

Карикатура још једном активира метафору зидА и сликовну схему САДРЖАВАњА, те перцепирање миграната као „они”, „други”, 
„неприпадајући”, којима се мора онемогућити „поход” на ЕУ, која је овде обележена симболом звездица и плавом бојом као метонимичним представама ЕУ. Одбрана простора САДРЖАТЕљА ЕУ жичаном оградом коју „красе” златне звездице, симбол јединства и заједништва, сугерише да се мигранти поимају као извор страха и нестабилности, па се кретању миграната и њиховом доласку на крајње одредиште - ЕУ, те уласку у простор државе као САДРЖАТЕљА ЕУ мора супротставити.

Последња карикатура (Слика 8) такође је пример мономодалне, сликовне метафоре, коју, смештањем у одговарајући друштвени контекст, јасно идентификујемо као метафору чији је циљни домен МИГРАНТСКА КРИЗА. Циљни домен је и вербално помогнут насловом „Избеглице”

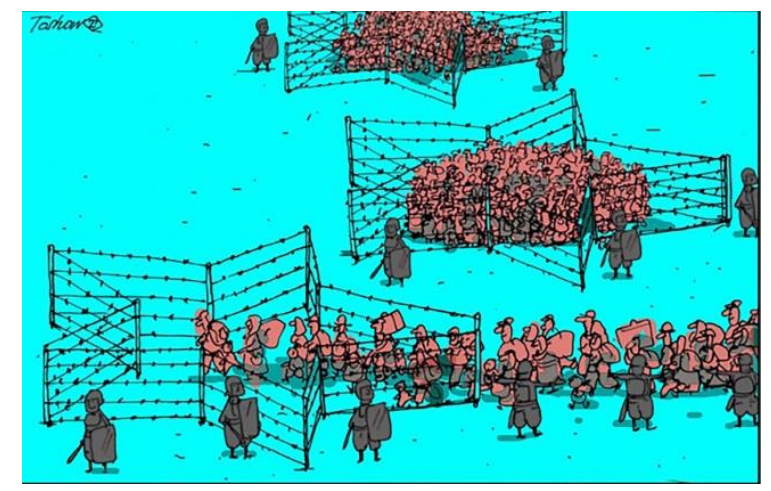

Слика 8. Вечерње новости, 25. август 2015. год. Наслов: Избеглиие

Карикатуром доминира слика миграната које на границама држава припадници полиције спроводе у жичане ограђене просторе. У контексту актуелне ситуације, ограђени простори визуелна су реализација (појединих) држава чланица ЕУ (на појмовном плану схема САДРЖАВАФА) које на својим границама постављају жичане ограде и препреке за даље кретање миграната. Но, виђено из критичког приказа карикатуристе, државе Уније поимају мигранте као непријатеље које је потребно затворити и оградити жицом у просторе који подсећају на логоре (као САДРЖАТЕЉЕ). Другим речима, ако мигранти и постану САДРЖАНИ ОБЈЕКТИ, визуализација изолације и неприпадања одређеном простору јасно је истакнута. Уочава се да аутор визуелним путем настоји да дочара и размере мигрантске кризе, где се велики број миграната у приказу другог и трећег ограћеног простора на слици приказује као безоблична маса људи, што у аксиолошком 
смислу води ка метафори ВИШЕ JЕ ЛОШЕ, тј. има негативно вредносно одређење.

\section{ЗАКЉУЧАК}

Актуелна друштвена појава са далекосежним последицама европска мигрантска криза - анализира се у овом раду са аспекта мултимодалности у карикатури, жанру који се ретко истражује у лингвистичким оквирима на српском језику. Анализа омањег узорка од дванаест карикатура објављених у дневним листовима Политика и Вечерње новости показала је да се у интерпретацији карикатура активирају доминантни когнитивни модели САДРЖАВАФА и КРЕТАЊА, као и други когнитивни механизми који у спрези доприносе одређеном појмовном представљању кључних актера, миграната и Европске уније у мултимодалном дискурсу. Заједничко за све анализиране карикатуре јесте поимање ЕУ као КУЋЕ или зГРАДЕ која свој унутрашњи простор брани подизањем жичаних и бетонских зидова или затварањем врата, чиме се мигранти перципирају као уљези, нежељени гости и непожељни „туристи”. Осим сликовних схема и метафора, важна улога припада и метонимијама, посебно оним заснованим на односу ДЕО-ЦЕЛИНА, које су најчешће визуелно оваплоћене, посебно кроз симболе везане за ЕУ. Од осам анализираних карикатура, шест су примери мултимодалних метафора и представљају успешан спој слике и текста. Вербалне реализације додатно појачавају визуелни критички приказ мигрантске кризе и превасходно улогу и одлуке ЕУ из угла карикатуристе као „гласа народа”.

Уопште узев, наша анализа мултимодалног дискурса политичке карикатуре потврдила је да су визуелни модалитети когнитивних структура неретко ефектнији у структурисању одређених аспеката друштвене стварности од оних вербалних, будући да је њихово значење много сугестивније и подложније различитим интерпретацијама. Поимање апстрактног појма какав је овде европска мигрантска криза у оквиру жанра карикатуре готово је немогуће изразити без метафоре, визуелно или вербално реализоване, и других когнитивних механизама, попут метонимије, која се увек јавља у визуелном модалитету. Како и визуелне метафоре, попут својих вербалних пандана, служе као средство перспективизације и усмеравања пажње на један део одређеног појма, оне постају одраз избора карикатуристе и његовог критичког става према европској мигрантској кризи, те мултимодални облик перцепције које о том друштвеном питању има широка читалачка публика. Другим речима, слика омогућава идеолошки бременит угао посматрања. У том погледу, визуелне метафоре, како се у анализи показује, веома су зависне од контекста за који се везују, како непосредног, сликовног често помогнутог језичким средствима, 
тако и ширег, друштвено-политичког и културног контекста. Отуд је значење визуелних метафора најчешће имплицитно, путем симбола (или других визуелних решења), који подвлаче културне, расне, идеолошке и друге разлике, те подстичу заузимање вредносних ставова. Описани визуелни модалитети когнитивних структура, сликовних схема, метафора и метонимија, разоткривају негативну аксиолошку вредност, те, слично вербалној метафори, имају изражену реторичку функцију и могу ефектније од речи узбуркати емоције читалаца. То се нарочито очитује у визуелним примерима метафоре зидА, најчешћом на приказаним карикатурама, којом се указује на дубоко уврежене бинарне поделе на „нас” и „њих”, те маргинализацију друштвених група и неједнакост у односима моћи, овде на примеру европске мигрантске кризе.

Додатна истраживања на већем корпусу карикатура, на основу којег би се анализирала мигрантска криза, као и контрастирање са карикатурама у дневној штампи на другим језицима, могла би да укључе и друге когнитивне моделе и метафоре преко њихових визуелних и/или вербалних реализација, што би допринело свеобухватнијој концептуализацији ове друштвене појаве.

\section{ЛИТЕРАТУРА}

Barcelona, A. (2011). Reviewing the properties and prototype structure of metonymy. In: R. Benczes, A. Barcelona, \& F. J. Ruiz de Mendoza Ibáñez (Eds.), Defining metonymy in cognitive linguistics: Towards a consensus view (pp. 7-57). Amsterdam/Philadelphia: John Benjamins Publishing Company.

Benczes, R., Barcelona, A., \& Ruiz de Mendoza Ibáñez, F. J. (Eds.) (2011). Defining metonymy in cognitive linguistics: Towards a consensus view. Amsterdam/ Philadelphia: John Benjamins Publishing Company.

Благојевић, С., \& Ралевић, Т. (2013). Криза штампе, али не и карикатуре: пример анализе политичке карикатуре у дневној штампи [The crisis of the press, but not of a caricature: An example of the analysis of political caricatures in the daily press]. Медијски дијалози, 16, 369-385.

Bounegru, L., \& Forceville, C. (2011). Metaphors in editorial cartoons representing the global financial crisis. Visual Communication, 10(2), 209-229.

Charteris-Black, J. (2004). Corpus approaches to critical metaphor analysis. Basingstoke/ New York: Palgrave Macmillan.

Charteris-Black, J. (2006). Britain as a container: Immigration metaphors in the 2005 election campaign. Discourse \& Society, 17(6), 563-582.

Cortés de los Ríos, M. E. (2010). Cognitive devices to communicate the economic crisis: An analysis through covers in The Economist. Ibérica, 20, 81-107.

Dervinyte, I. (2009). Conceptual EMIGRATION and IMMIGRATION metaphors in the language of the press: A contrastive analysis. Studies about Languages, 14, 49-55.

Ђуровић, Т. (2015). Cognitive linguistics meets critical discourse analysis: The representation of asylum seekers in Serbian. У: Б. Мишић-Илић, \& В. Лопичић (ур.), Језик, књижевност, дискурс [Language, literature, discourse] (стр. 283ч295). Ниш: Филозофски факултет. 
Ђуровић, Т., \& Силашки, Н. (2013). Улога сликовних схема у метафоричком структурисању светске економске кризе у енглеском и српском језику [The role of image schemas in the structuring of the global economic crisis in English and Serbian]. У: Н. Силашки, \& Т. Ђуровић (ур.), Актуелне теме енглеског језика науке и струке у Србији [Current topics in English for specific purposes at tertiary level in Serbia] (стр. 133-146). Београд: ЦИД Економског факултета.

El Refaie, E. (2001). Metaphors we discriminate by: Naturalized themes in Austrian newspaper articles about asylum seekers. Journal of Sociolinguistics, 5(3), $352-371$.

El Refaie, E. (2003). Understanding visual metaphor: The example of newspaper cartoons. Visual Communication, 2(1), 75-96.

El Refaie, E. (2009). Metaphor in political cartoons: Exploring audience responses. In: C. J. Forceville, \& E. Urios-Aparisi (Eds.), Multimodal metaphor (pp. 173-197). Berlin/New York: Mouton de Gruyter.

Forceville, C. (2008). Metaphor in pictures and multimodal representations. In: R. W. Gibbs, Jr. (Ed.), The Cambridge handbook of metaphor and thought (pp. 462482). Cambridge: Cambridge University Press.

Forceville, C. (2009). Non-verbal and multimodal metaphor in a cognitivist framework: Agendas for research. In: C. J. Forceville, \& E. Urios-Aparisi (Eds.), Multimodal metaphor (pp. 19-42). Berlin/New York: Mouton de Gruyter.

Forceville, C., \& Urios-Aparisi, E. (2009). Introduction. In: C. J. Forceville, \& E. Urios-Aparisi (Eds.), Multimodal metaphor (pp. 3-17). Berlin/New York: Mouton de Gruyter.

Hart, C. (2010). Critical discourse analysis and cognitive science: New perspectives on immigration discourse. Basingstoke: Palgrave Macmillan.

Hart, C., \& Cap, P. (Eds.) (2014). Contemporary critical discourse studies. London/New York: Bloomsbury Publishing Plc.

Johnson, M. (1987). The body in the mind: The bodily basis of meaning, imagination, and reason. Chicago: University of Chicago Press.

Koller, V. (2009). Brand images: Multimodal metaphor in corporate branding. In: C. J. Forceville, \& E. Urios-Aparisi (Eds.), Multimodal metaphor (pp. 45-71). Berlin/New York: Mouton de Gruyter.

Kövecses, Z. (2010). Metaphor. A practical introduction ( $2^{\text {nd }}$ ed.). Oxford: Oxford University Press.

Lakoff, G., \& Johnson, M. (1980). Metaphors we live by. Chicago/London: University of Chicago Press.

Martínez Lirola, M. (2008). A critical analysis of the image of immigrants in multimodal texts. Linguistics and the Human Sciences, 06/2008, 2(3), 377397. doi: $10.1558 /$ lhs.v2i3.377

Musolff, A. (2011). Migration, media and "deliberate metaphors". metaphorik.de, 21/2011, 7-19.

Musolff, A. (2015). Dehumanizing metaphors in UK immigrant debates in press and online media. Journal of Language Aggression and Conflict, 3(1), 41-56.

Negro Alousque, I. (2013). Visual metaphor and metonymy in French political cartoons. RESLA, 26, 365-384.

Negro Alousque, I. (2014). Pictorial and verbo-pictorial metaphor in Spanish political cartooning. Círculo de Lingüística Aplicada a la Comunicación, 57, 59-84.

Radden, G., \& Kövecses, Z. (1999). Towards a theory of metonymy. In: K.-U. Panther, \& G. Radden (Eds.), Metonymy in language and thought (pp. 17-59). Amsterdam/Philadelphia: John Benjamins. 
Reisigl, M., \& Wodak, R. (2001). Discourse and discrimination. Rhetorics of racism and antisemitism. London/New York: Routledge.

Santa Ana, O. (2002). Brown tide rising: Metaphors of Latinos in contemporary American public discourse. Austin, TX: University of Texas Press.

Силашки, Н., \& Ђуровић, Т. (2013). The FOOD metaphor in structuring the global financial crisis in Serbian - Magazine covers as multimodal discourse. In: A. Soares da Silva, J. Candido Martins, L. Magalhaes, \& M. Goncalves (Eds.), Comunicação Política e Económica. Dimensões Cognitivas e Discursivas (pp. 507-520). Braga: Faculdade de Filosofia, Universidade Católica Portuguesa.

\title{
MULTIMODALITY AND THE MIGRANT CRISIS IN SERBIAN NEWSPAPER CARTOONS
}

\author{
Tatjana Đurović \\ University of Belgrade, Faculty of Economics, Belgrade, Serbia
}

\begin{abstract}
Summary
The topic of migration is gaining extensive media coverage in Serbia since it is emotionally loaded and may thus provoke different reactions among the public. The paper is set within the context of the current social situation with the migrant crisis reaching drastic proportions both in the transit countries for migrants, Serbia being one of them, and in some EU member countries as the migrants' final destination. This, in turn, has made some EU member states, Hungary and Croatia in particular, decide to build the wall in order to protect not only their national boundaries, but the EU's external boundaries as well. Following closely Serbian press in regard to Europe's migrant crisis we have noticed that in addition to language, this complex social issue is represented via some other semiotic system as well - pictures. Hence, complementing a wide theoretical framework of cognitive linguistics (Lakoff \& Johnson, 1980; CharterisBlack, 2004; Kövecses, 2010) with multimodality (Forceville, 2009; Forceville \& UriosAparisi, 2009; Bounegru \& Forceville, 2011) which focuses here on a genre of cartoons, the paper explores how cartoonists use visual and/or verbal realisations of the CONTAINMENT and MOVEMENT image schemas as well as metaphors and metonymies grounded on these schemas to metaphorically structure a complex social issue, that of the migrant crisis and highlight the key participants in the crisis, migrants and the EU.

Our analysis of multimodal discourse from a cognitive linguistic perspective is based on a small data collection of twelve cartoons published in 2015 in two daily newspapers, "Politika" (six cartoons) and "Večernje novosti" (also six cartoons). The paper qualitatively analyses eight cartoons with the aim of: i) identifying and describing monomodal and/or multimodal cognitive instruments deployed to conceptualise the migrant crisis, and ii) unveiling how visual and/or verbal modalities of metaphor and other cognitive instruments convey an axiological value and more or less covert ideological stances. The analysis of the selected Serbian political cartoons shows that the EU is conceptualised as a HOUSE or BUILDING which protects its inner space by erecting razor wire fences and concrete walls or by closing the door which thus contributes to viewing migrants as intruders, unwelcome guests and undesirable "tourists". In addition to two image schemas - CONTAINMENT and MOVEMENT and the metaphors of WALL, HOUSE, BUILDING and JOURNEY, metonymies also
\end{abstract}


have a significant role in structuring the migrant crisis, particularly those of the PARTWHOLE type which are mostly visually rendered especially via symbols related to the EU. Six cartoons out of the eight analysed in the paper are examples of multimodal metaphors and accentuate the complementarity of image and text in conveying a message to the reader. More specifically, the selected cognitive instruments, primarily when they are visually rendered, as well as when visual and verbal realisations of metaphor in the same cartoon are mutually contradictory, are a powerful vehicle that cartoonists use to take a critical attitude particularly towards the EU's role and decisions pertaining to the migrant crisis, and thus impact on the readership. On the whole, visual instantiations of the cognitive structures - image schemas, metaphors and metonymies, convey a negative axiological value and similarly to verbal metaphor have a prominent rhetorical function. The paper, therefore, stresses the importance of monomodal (pictorial) and multimodal metaphors in the construal of meaning, and the role of metaphors, metonymies and image schemas in the intended message of the cartoon. 